\title{
Challenges Facing Jordanian Universities in Activating Media Education among their Students
}

\author{
Talal Mathhan Al-Mhareb \\ Ph.D. student at College of Educational Sciences at the University of Jordan
}

\author{
Prof. Dr. Mohammad Saleem Al-Zboun \\ University of Jordan / Faculty of Educational Sciences / Department of Educational Leadership and Foundations
}

\begin{abstract}
This study aims to identify the challenges facing Jordanian universities to activate media education among their students from the viewpoint of the students themselves. To achieve the objective of the study, a questionnaire consisting of (20) items is distributed to Jordanian university students (332) from the Jordanian public universities (University of Jordan, Yarmouk University, and Mu'tah University, along with the survey method. The results of the study show that the challenges facing Jordanian universities to activate media education among their students for Jordanian university students are of a medium degree in terms of the arithmetic mean of (3.55). Based on the results of the study, the study recommends adopting an approach by the Jordanian universities to support media education in a manner contributing to increasing the efficiency and ability of the academic and administrative staff and students in all Jordanian universities to enrich the learning and teaching process.
\end{abstract}

Keywords: media education, Jordanian universities, students of Jordanian universities.

DOI: $10.7176 / \mathrm{JEP} / 11-22-07$

Publication date:August $31^{\text {st }} 2020$

\section{Introduction}

Media is an essential element in contemporary societies, especially after the outbreak of the revolution in telecommunications, the progress of work and knowledge, and the application of scientific theories in all areas of work and life. As those societies become more advanced, they need more information because the media is a central means of spreading ideas and a way of education. Media, in general, is an important means of communication and affects the behavior of individuals with its various values.

Today, individuals of society live in a world where information is attained around the clock and in all formulas, whether audible, readable, or visual, information that holds values and trends that contradict or do not contradict the culture of society. This information has become a double-edged sword as it is available to everyone's various ages, making privacy lose its content due to the wrong openness. Accordingly, media education has to deal with this new reality and its messages that affect emerging behaviors and direct them according to their media content (Mutairi, 2012).

The concept of media education is not a novel talk and term, as it appeared in the late sixties of the last century when experts begin to pay attention to the use of communication tools and the media as an educational method to achieve tangible educational benefits. In the late seventies of the last century, media education is viewed as an education related to media and a defense project whose goal is to protect children and youth from the dangers created by the media, where the emphasis is directed into exposing fake messages and encouraging university students to overlook and reject them. In recent years, the concept of media education has evolved from a defense project to an empowerment project that aims to prepare young people to understand the media culture surrounding them, deal with it scientifically, and participate in it effectively and efficiently to face contemporary challenges (Shamary, 2010).

Currently, universities shall be aware of the importance and role of the media in facing contemporary challenges as an area that can be employed in the educational field. The role of media education in universities must be activated because of increased awareness among students in benefiting from the intellectual contents provided by the media based on sound scientific foundations whether they are at the level of the individual or society. These intellectual contents work to develop critical thinking among members of society, which leads to the acquisition of comparison and analysis skills, decision-making, and problem-solving skills. Also, media education enhances the confidence of the individuals themselves as it provides them with a comprehensive image of the media environment in terms of its various means and individual's ability to be part of it as a result of technological development, allowing them to be involved in achieving social security. At the level of society, media education, in general, is an important factor in spreading the culture of dialogue that leads to positive generations able to participate effectively in developing, building their society, and facing the challenges facing it (Erekat, 2017).

The media education's content in universities must be characterized by a set of characteristics based on several axes compatible with the era of digital culture to produce a generation capable of facing cultural challenges 
in light of the tremendous development and media momentum to achieve media awareness of its students. Among these cultural challenges is the protection of young people and youth from the negative effects of the media's contents and various aspects, especially in the age of globalization, the development of critical thinking skills, the acquisition of university students to the basic principles of analyzing, interpreting, and critiquing all of the media content provided with intended and unintended goals, providing university students with the information and knowledge necessary to help them to understand the ideologies of the media, and create a strong, productive and creative generation that contributes to developing his country. Media education, such as educational institutions, teaches us to read, monitor, learn, and listen (Muslim, Aziz, and Jaballah, 2017).

Smet (2013) indicates that the importance of activating media education in universities lies in supporting university students' acquisition of the skills and experience needed to understand the media mechanism to prepare them for media participation in light of society's ethics and controls. To bring about changes in the level of internal organization in universities as educational institutions, they should aim to improve the management of human and economic resources, restructure them to improve internal democracy, and continue their mission to educate, train and implement research through an ethical, autonomous, transparent and accountable approach. Creating change is the biggest challenge at several levels, which are changes in knowledge creation, changes in the educational model, changes that aim to take advantage of the potential of information and communications technology to create and spread knowledge, and changes in social responsibility and knowledge transfer (Skik, 2019).

Al-Zboun, Jaafara, and Mawadia (2016) also show that one of the most important current challenges facing higher education is the mismatch between the skills taught and the skills demanded by employers, which leads several problems such as the high rate of unemployment, the urgent need to increase government spending on higher education to meet demand growing on this type of education, restriction of Jordanian universities to the local space with some exceptions and their lack of interaction with international sources, whether in attracting foreign students, faculty members, or sources of scientific and technical knowledge, in addition to the very slow level of Jordanian university administrations in responding to the demands of change and development. As a result of the complexity of bureaucratic organizations and the prolongation of a series of levels with powers in educational decision-making, the science and use of technical challenge is one of the biggest challenges facing Jordanian and non-Jordanian higher education policy, which needs reform and renewal.

In light of the aforesaid insight, it can be said that university education is a source of strength for any society. Through education, students are provided with knowledge, skills, values, attitudes, and abilities to face modern and future challenges, and it is one of the most effective ways in which societies can face existing challenges and problems. The achievement of progress and development for any society comes only with what the minds that masters the art of thinking produce, and the ability to investigate, create and innovate, which is compatible with global changes. Accordingly, the university can integrate media education in its educational programs and its teaching courses because the real richness lies in the students' abilities to know what is happening in the contemporary world, and how they can participate in it.

\section{Problem of the Study}

Educationally speaking, media education is one of the foundations that universities depend on to build the development plans and activate education in general because of its characteristics of diversity in an era that has witnessed tangible progress in audio-visual means and the media. It is also considered one of the most enjoyable and interesting methods close to the focus of students' interests, so it is imperative to reconsider media education, especially that university students are more vulnerable to its scope and affected by media material. As long as media education reflects on the knowledge and behavior of students in society, it requires a new formation that can deal with these developments in the field of media and communication so that new generations can acquire media education skills by building liberal critical thinking, so it is necessary to examine the reality of media education in universities to find out the challenges facing universities to activate media education for their students. Thus, the problem of the study lies in identifying the challenges facing Jordanian universities in activating media education for their students.

\section{Question of the Study}

In light of the problem of the study, the following question is formatted.

What are the challenges facing Jordanian universities to activate the role of media education for their students from the students' viewpoint?

\section{Objective of the Study}

Explore the challenges facing Jordanian universities to activate the role of media education for their students from the students' viewpoint. 


\section{Significance of the Study}

The significance of the study appears in its expected results related to the field of media education. It is hoped that decision-makers will benefit from the study results by drawing the attention of those at the Ministry of Higher Education of the need to include media education in university courses and other related general activities. Also, the authors of future political plans at the Ministry of Higher Education can make use of this study by facilitating the access of university students to the skills and expertise they need to understand how the media shapes their awareness and prepares them to participate as decision-makers and participants in virtual societies within the ethics of society. Besides, this study may help researchers and those interested in this field of media education by opening the door for conducting and developing future studies in the same field.

\section{Terms of the Study}

Due to the nature of the study, the current study adopts the following terms:

Media education: it is defined as enabling the student with media skills that explain to him how to properly deal with the media material so that he will be able to access, benefit from media messages, express his point of view in the media contents and form a critical analytical view of what is presented in media messages accurately, encourage him to communicate and participate creatively through the media, and produce media materials that serve religion, science and society. It is also procedurally defined as a series of procedures that the university rely on to enable students to make optimal use of the media and benefit from all the privileges it provides and can be used in the educational aspect, and it can be measured through the response of the members of the study sample to the instrument prepared for this purpose (Qarni, 2019)

Challenges: are the difficulties and obstacles that prevent the university from fulfilling its role in activating media education and its foundations.

\section{Previous Studies}

Several previous studies have been done on the importance of media education. Hendriyani \& Guntarto's study (2011) defines the concept of media education in Indonesia and assess the variance in the definition of the term. To determine the strategies of media education in Indonesia, the researcher has used the descriptive-analytical approach. The study shows that there are two teams in the definition of media education where the first team knows it as a way to protect individuals from the negative influence of the media, while the second team knows it as the way to raise the economic, cultural and educational level of the state, and that all state institutions are responsible for media education and not only the responsibility of educational institutions.

Zhong's study (2015) aims at identifying the importance of the role played by media education in the stage of university education. To achieve the goals of the study, the analytical method is used. The study shows that while the media education's relationship to political and ideological education seems very clear, there are some factors with negative effects in this regard. First, the lack of knowledge background of university leaders about media education, as most university leaders are not able to change their opinion regarding the development of social education and are still convinced that ideological and political education in the stage of a university education should depend on teaching only. Second, the inevitable campus culture of a student must be changed as it does not know the culture of media education. Third: The students themselves are still accustomed even at present to just reading the media content without criticism or analysis. The results of the study show that the ideological and political education at the university stage still has a lot to do and media education can play a big role in this regard.

Koc \& Barut's study (2016) aims at testing and developing a measure for the new media education for university students, and the descriptive method is used. The study sample consists of (1226) students from State University in Turkey, where the study has developed an effective psychological measure to evaluate media education. The study shows that the new media and digital technology will transform individuals from consumers into individuals who can produce, exchange, share, and criticize digital content. The results of the study show that there are statistically significant differences between the arithmetic means of the respondents' response to the test designed to develop and measure media education among students for the benefit of the bachelor degree students and that there are no statistically significant differences attributed to the gender variable.

Belkassi's study (2017) aims at identifying the degree of university student awareness of the subject of media education, the role of university education curricula in achieving media education, and identifying the mechanisms for including media education in the curricula. The study has adopted the field survey method, and the study population consists of students of the Faculty of Information and Communication at the University of Algeria, and a purposeful sample of (39) students is selected. The results of the study show that the acquisition of media education skills through curricula is necessary for students, including the refinement of individual skills with critical and creative thinking, decision-making, and continuous learning for a lifetime. The study shows that students' awareness of media education is developing directly with an increase in their educational level.

Besides, Qutb's study (2018) aims at identifying the degree of youth's knowledge of the principles of media 
and digital education and the relationship of this to some variables and their communicative behavior through social networking sites and applications. The researcher has used the survey and comparative approach. The study population consists of Egyptian youth who use social networking sites (Facebook and Instagram). A random sample consisting of 200 young men and women with age of (18-35) is selected. The results show that $70.5 \%$ of the respondents do not know the term media education and that there are statistically significant differences for the extent of youth's awareness of the principles of media education due to the age variable and in favor of the age group (24-30). The study also shows that there are statistically significant differences for the extent of youth's awareness of the principles of media education due to the variable of the educational level (intermediate, university qualification, graduate studies). The results also show a statistically significant correlational relationship between youth's awareness of the principles of media education and their behavior on social media.

Of note, the forgoing studies are used to design the theoretical framework and develop the instrument. Also, the current study differs from previous studies as it addresses the challenges facing Jordanian universities to activate media education among their students from the students 'viewpoint themselves. Moreover, this study is considered one of the first studies to address this topic in Jordan.

\section{Limitations of the Study}

This study is limited to explore the challenges facing Jordanian universities in activating media education for their students. It is also limited to a randomly selected sample of students from Jordanian public universities (University of Jordan, Yarmouk University, and Mu'tah University distributed in the three regions of the Kingdom. Moreover, it is applied in the $2^{\text {nd }}$ semester of the academic year 2019/2020.

\section{The Methodology of the Study}

To achieve the research objectives, the survey method is used.

\section{Study population}

The study population consists of (7239) students from Jordanian public universities for the academic year $2019 / 2020$.

\section{Study Sample}

The sample of the study consists of (332) male and female students according to the random sample schedule for the population study to represent the three universities.

\section{Study Instrument}

The study instrument is developed by referring to theoretical literature and previous studies dealing with media education such as the Belkassi's study (2017) and Qutb's study (2018) to develop the study instrument in its initial form to define the role of media education in facing contemporary challenges from the viewpoint of Jordanian university students as the instrument's items are (20) items designed based on a five-dimensional Likert scale.

\section{Instrument's Validity}

To verify the validity of the content of the study instrument, the content is presented to a group of experts and specialists in Jordanian universities to express their views in the questionnaire items in terms of clarity of meaning, linguistic construction, and the degree of suitability for the field to which it belongs, and any other appropriate modifications and notes. $(80 \%)$ of the validators' comments are taken into consideration to achieve the objectives of the study without neglecting to make the proposed modifications to any modification to the linguistic construction of the items. Later on, the study's instrument is finalized.

\section{Instrument's Reliability}

The stability of the study instrument is verified by measuring the internal consistency using the Cronbach-Alpha equation, and the value of the study instrument reliability coefficient is $(0.89)$ which is considered as a valid result for the study.

\section{Statistical Processing}

The degree of the importance of the role of media education in facing contemporary challenges is determined from the viewpoint of Jordanian university students by responding to the study sample on the Likert five-point scale by giving each of its items one of its five degrees (Strongly disagree, Disagree, Neither agree nor disagree, and Agree Strongly agree), which represents digitally $(5,4,3,2,1)$ respectively. The statistical processing for data is performed in this study using the Social Sciences Statistical Package (SPSS). The criterion for judging the means of the study instrument is determined by dividing it into three degrees: low, medium, and high, according to the following: 
formula:

Category length $=$ Highest value of the substitute - the minimum value of the substitute / Number of levels $1.33=3 /(1-5)=$

Accordingly, the following criterion is used to calculate the responses of the study sample:

The low score is less than 2.33 .

The medium score is from 2.34 to 3.67 .

The high score is from 3.68 to 5.00 .

\section{Results and Discussion}

The discussion and results related to the question of the study are as follow:

- What are the challenges facing Jordanian universities to activate the role of media education for their students from the students' viewpoint?

To answer this question, arithmetic means and standard deviations are calculated as shown in Table (1).

Table 1: Arithmetic Means and Standard Deviations, Rank, and Degree for the Study Sample Estimates of the Challenges Facing Jordanian Universities to Activate the Role of Media Education for their Students in Descending Order

\begin{tabular}{|c|c|c|c|c|c|c|}
\hline No. & $\begin{array}{l}\text { Item } \\
\text { No. }\end{array}$ & Item & $\mathrm{AM}$ & SD & Rank & Degree \\
\hline 1 & 14 & $\begin{array}{l}\text { The inability of university institutions to develop the human } \\
\text { resources that possess the necessary competence to keep } \\
\text { abreast of developments regarding media education. }\end{array}$ & 3.98 & 1.05 & 1 & High \\
\hline 2 & 19 & $\begin{array}{l}\text { Undergraduate courses fail to include the principles of media } \\
\text { education as a democratic necessity. }\end{array}$ & & 0.99 & 2 & High \\
\hline 3 & 17 & $\begin{array}{l}\text { Failure to provide the necessary support for students to } \\
\text { research in media education. }\end{array}$ & 3.87 & 0.93 & 3 & High \\
\hline 4 & 15 & $\begin{array}{l}\text { The absence of a clear long-term strategic vision for } \\
\text { university decision-makers. }\end{array}$ & 3.86 & 0.96 & 4 & High \\
\hline 5 & 7 & $\begin{array}{l}\text { Lack of awareness of (strengths, weaknesses, opportunities, } \\
\text { and threats) within the university institutions to maximize the } \\
\text { use of opportunities and confront threats in the field of media } \\
\text { education. }\end{array}$ & 3.81 & 1.01 & 4 & High \\
\hline 6 & 9 & $\begin{array}{l}\text { Faculty members lack the skills to employ the principles of } \\
\text { media education while teaching us. }\end{array}$ & 3.81 & 1.05 & 6 & High \\
\hline 7 & 20 & $\begin{array}{l}\text { Universities lack new (disciplines and new academic } \\
\text { programs) that harmonize together to develop media } \\
\text { education while teaching us. }\end{array}$ & 3.68 & 1.03 & 7 & Medium \\
\hline 8 & 16 & $\begin{array}{l}\text { Universities suffer from a lack of financial means represented } \\
\text { by (devices, laboratories, etc.). }\end{array}$ & 3.66 & 1.17 & 8 & Medium \\
\hline 9 & 8 & Media lack of media credibility. & 3.57 & 1.10 & 8 & Medium \\
\hline 10 & 18 & $\begin{array}{l}\text { Universities suffer from a lack of clarity in the importance of } \\
\text { media education among decision-makers. }\end{array}$ & 3.57 & 1.02 & 10 & Medium \\
\hline 11 & 10 & $\begin{array}{l}\text { The university administration lacks participation with } \\
\text { students in the decision-making process to spread the } \\
\text { concepts of media education. }\end{array}$ & 3.54 & 1.04 & 11 & Medium \\
\hline 12 & 11 & $\begin{array}{l}\text { Poor consistency between the educational system inputs and } \\
\text { outputs. }\end{array}$ & 3.50 & 1.06 & 12 & Medium \\
\hline 13 & 13 & The lack of media resources qualified to teach students. & 3.48 & 1.16 & 13 & Medium \\
\hline 14 & 12 & $\begin{array}{l}\text { The lack of activities undertaken by the Deanship of Student } \\
\text { Affairs to develop concepts of media education. }\end{array}$ & 3.43 & 1.17 & 13 & Medium \\
\hline 15 & 1 & Students lack the skills to interact with social media. & 3.43 & 1.17 & 15 & Medium \\
\hline 16 & 3 & $\begin{array}{l}\text { The university suffers from adherence to a traditional } \\
\text { administrative method that avoids its students from benefiting } \\
\text { from the emerging administrative ideas data. }\end{array}$ & 3.37 & 1.24 & 15 & Medium \\
\hline 17 & 5 & Students' lack of meaningful constructive dialogue. & 3.37 & 1.07 & 17 & Medium \\
\hline 18 & 4 & $\begin{array}{l}\text { Students lack the values of respecting the privacy of the other } \\
\text { when dealing with the means related to media education. }\end{array}$ & 3.36 & 1.08 & 18 & Medium \\
\hline 19 & 6 & $\begin{array}{l}\text { Students treat media education as a free platform without } \\
\text { controls. }\end{array}$ & 3.34 & 1.03 & 19 & Medium \\
\hline
\end{tabular}




\begin{tabular}{|l|l|l|l|l|l|l|}
\hline No. & $\begin{array}{l}\text { Item } \\
\text { No. }\end{array}$ & Item & AM & SD & Rank & Degree \\
\hline 20 & 2 & $\begin{array}{l}\text { Students lack sufficient awareness to deal with various } \\
\text { sources of information. }\end{array}$ & 3.24 & 1.11 & 20 & Medium \\
\hline & & 3.23 & 0.84 & & Medium \\
\hline
\end{tabular}

Table (1) shows that the challenges facing Jordanian universities to activate media education for their students from the students' point of view are medium, so the arithmetic averages have ranged between (3.98 to 3.23), and concerning the total degree, it is also medium in terms of the arithmetic mean which is of (3.55). This may be due to the recognition of the importance of the availability of media and digital education skills and tools because it tracks their development and their access to the social life of students at all levels, so it is necessary to make the distances between the modern means of communication in media technology close on the one hand and the upbringing of the young on the other hand to use it positively and avoid its risks. Media education is part of the basic rights of every student in Jordanian universities, and the need to include them in educational curricula to develop students and provide them with skills and ability to keep abreast of current developments. Also, this may be attributed to the need for Jordanian universities to develop human resource skills on the principles of media education from effective self-criticism, and expose fraud methods followed by the yellow media in a way that contributes to forming an opinion and a sound decision aware of developments taking place to keep pace with the developments of the times.

Moreover, this may be due to the presence of a conviction by Jordanian university students that the principles of media education should be included in the study plans of all disciplines. Incorporating media education in courses contributes to the students' qualification process and enables them to deal in a sound and positive manner with modern information sources, and the means of communication as a free platform with controls and laws that must be observed to preserve the private space of others to acquire a set of skills that help them work according to future developments by promoting media education from training courses and electronic services. This is also due to the need for the continued support of Jordanian universities for researchers and scientific research to preserve human capital from immigration or even a feeling of frustration to develop the researcher's mindset so that he becomes a product of knowledge and science and not merely a memorizer of information that already exists, and an analyst of the aspects related to the topic of research to develop the educational scientific process and the development of the professional and academic aspect of universities

Importantly, this is also due to the need for universities to support students through their participation in conferences and scientific forums so that students acquire intellectual and practical skills to develop the privacy values of others while dealing with the means of communication as a free platform with controls that must be respected and not overcome. More importantly, this may also be due to the students' keenness on the necessity of qualifying them for the proper and safe handling of communication means to be able to differentiate between the correct, innocent, and credible media, and the politicized and directed media that lacks credibility, the mechanism for dealing with various media, and how to benefit from them, and how to use them for the development of university students and the development of their knowledge and culture.

\section{Recommendations}

In light of the results of the study, several recommendations are attained such as the need for Jordanian universities to adopt an approach that supports media education in a manner that contributes to increasing the efficiency and ability of academic and administrative staff and students in all Jordanian universities to enrich the learning and teaching process, the need for Jordanian universities to include media education in their educational programs and teaching courses to combat media negatives, the necessity of conducting training courses to qualify the academic and administrative staff and students of Jordanian universities on how to use contemporary modern technologies, and the necessity of diversifying faculty members with the teaching methods and methods based on the principles of media education through modern technologies.

\section{References}

\subsection{References in Arabic}

Al-Zboun, Muhammad and Jaafara, Abdul Salam Mawadia, Rida. (2016). The Education System in Jordan, Wael Publishing House: Amman, Jordan.

Belkassi, Karim. (2017). The role of university education curricula in achieving media education: An exploratory study of a sample of students from the Faculty of Information and Communication at the University of Algeria. The Journal of Humanities Studies and Research, 1 (2), 111-134.

Erekat, Ahmed. (2017). The Role of Media Education in Intellectual Security, International Media Conference: Media between Hate Speech and Intellectual Security, Zarqa University, 587-595

Hendriyani, M \& Guntarto, B. (2011). Defining Media Literacy in Indonesia, International Association of Media Communication Research, Turkey: Istanbul. 
Koca, M and Barut, E . (2016). Development and validation of new media literacy scale (NMLS) for university students. Computer in Human Behavior, 63, 834-843.

Muslim, Mahmoud and Aziz, Abdel Salam, and Jaballah, Ahmed. (2017). Developing awareness of media education in the light of academic standards. Journal of Educational Knowledge, 5 (9), 166-190.

Mutairi, Khaled. (2012). A proposed management strategy to employ media education in the practices of educational leaders at the Ministry of Education in Saudi Arabia, unpublished doctoral thesis, University of Jordan, Amman.

Qarni, Fatima. (2019). The reality of media education in public education institutions in the Kingdom of Saudi Arabia: Jeddah governorate as a model. Journal of Educational and Psychological Sciences - Arab Journal of Science and Research Publishing, 12 (3), 121-149.

Qutb, Fatima. (2018). The relationship between youth's awareness of the principles of media and digital education, and their communicative behavior on social networking sites and applications. Arab Journal for Media and Communication Research, (23), 212-236.

\subsection{References in English}

Shamary, Fahd. (2010). Media Education: How We Deal with the Media, King Fahd National Library for Publication: Riyadh.

Skik, Samia. (2019). Suggested future alternatives to develop graduate studies systems in Palestinian universities: A comparative orientalist perspective. Arab Center for Education and Development, 26 (116), 500-510.

Smet, P. (2013). Media Education: A Quality Study of Media Education Awareness Among Youths of Moscow University in Terms of National Academics Standards. Institute Voor Samenleving \& Technologies (IST): Vlaams. Zhong, L .(2015). Education of media literacy and ideology \& politics. Creative Education of Journalism \& Communication, 24 22-2426. 